\title{
Eating Well in Uncle's House: Bengali Culinary practices in a bucolic Calcutta/Kolkata in Amit Chaudhuri's A Strange and Sublime Address
}

\author{
Rajarshi Mitra \\ Indian Institute of Information Technology Guwahati, Ambari, Assam. \\ mitrarajarshi24@gmail.com
}

First published September 30, 2019

\begin{abstract}
:
Kolkata has had a long and troubled relationship with food and hunger, which has shaped Bengali food-practices in the city. From famine in the 1940's to food-movement of the 1960's, as food production dwindled, Kolkata saw a gradual decline of its economic fortune. In the 1970's and 8o's, it was common to portray Kolkata as a failed postcolonial metropolis filled with starving millions. With this troubled history in the backdrop, this paper focuses on culinary experiences in Kolkata as reflected in Amit Chaudhuri's novella A Strange and Sublime Address. The novella, in its bid to highlight the trivial and the mundane in Bengali life in Kolkata in the early 199o's, portrays culinary experiences as epiphanic expressions of an introverted, inner existence. Chaudhuri describes food-practices in an attempt to preserve an esoteric food-system - a system that connects inner life with cooking, serving and eating of food. Bengali food-practices, I argue, appear in this novella as "edible chronotopes" (Krishenblatt-Gimblett) revealing a culture's fascination with time and food. Through Bengali food practices the novella's protagonist Sandeep mourns a deep loss he feels about his lack of connection to Kolkata and learns to cultivate a sense of reticence, which allows him to absorb the joy of merging with the life in the city in its banal and quotidian form. I further connect Chaudhuri's search for the inner self in culinary practices with his journey to what he terms "bucolic" Kolkata - a journey Ashish Nandy had termed "an ambiguous journey to the city".
\end{abstract}

Keywords: city, food and hunger, culinary experience, post-colonialism, Amit Chaudhuri

\section{Introduction}

Yet behind the dread of homelessness is a desire for it, because the familiar world of our homes can be suffocatingly small. Perhaps it is impossible to know our authentic selves. We are forever mired in polarities of dread and desire for home and homelessness.

This story is in another sense a struggle to come home while fleeing from it. It is a return from Marxist utopia to the magic, myth, and tedium of cooking. It is the whittling down of big dreams into smaller ones. Two decades ago as I was becoming an intellectual, I also became a Marxist. As a Marxist I sought big questions, and in particular as a Third World Marxist I was compelled by the developmentalist promise of the Soviet experiment. After

(c) AesthetixMS 2019. This Open Access article is published under a Creative Commons Attribution Non-Commercial 4.0 International License (http://creativecommons.org/licenses/by-nc/4.o/), which permits non-commercial re-use, distribution, and reproduction in any medium, provided the original work is properly cited. For citation use the DOI. For commercial re-use, please contact editor@rupkatha.com. 
years of activism, I was confronted with martial law in Poland and the Soviet invasion of Afghanistan. (That feels so long ago now!) That is when my Marxism began to falter, which eventually took me on a route that led to this place-a retreat from the public drama into the private universe.

- (The Migrant's Table)

Calcutta, as a friend remarked, thrives on the underground - whether this be in the arena of political agitation, or in the new wonder, that is the metrorail, or in the subterranean passages of the minds of men and women.

An interior landscape, and highly complex.

- ("Portrait of A City")

In an article in 2010, Amit Chaudhuri claimed that authentic Bengali cuisine (and food) was in gradual decline. To establish his claim, he distinguished it from a hackneyed tale of general decline of Kolkata as a metropolis and Bengali culture. At least Bengali culture - its cinema and literature - is discussed, but Bengali food, Chaudhuri argues, remains "a well-guarded secret". Though much endorsed by "celebrity visitors" to the city, Bengali food is no more prepared the way it used to be, and its raw materials including fishes like hilsa, pabda and tangra do not taste the same. Chaudhuri distinguishes the taste of authentic Bengali food from spicy Indian recipes available in rest of India. Bengali food cooked in Bengali homes is "watery and insipid" and is "congruent" with bland English food. Tracing colonial roots behind this Bengal-English connection, he proposes three reasons for Bengali food being subtle, reticent and less flamboyant in taste. Firstly, there is the influence of nineteenth century "Bengali puritanism" with its emphasis on "self-denial, austerity, suggestiveness and the implicit in life, literature and taste". Secondly, despite Bengal's zealous embracement of cultural puritanism during colonial rule, Muslim influence has led to a mysterious syncretism which lies hidden underneath its "overdone and unpromising" look. Thirdly, the "cruel dietary regime" imposed on Hindu widows has engendered a "vegetarian repertoire unparalleled" with "condiments, ingredients and approaches" peculiar to Bengal. After listing several Bengali dishes, Chaudhuri laments that few restaurant chains in India respect the subtlety of Bengali cuisine, nor do they present an authentic Bengali fare. The one which did - "Oh! Calcutta" - "has lapsed into mediocrity" ("Decline"). Since 2010, however, Bengali cuisine has spread globally as newer restaurant chains have emerged in Kolkata and in cities with a sizeable Bengali diaspora. In Indian cities like Bangalore, Kolkata themed restaurants serve "authentic" Bengali cuisine ("Bengal to Bangalore"). This paper on Amit Chaudhuri's novella A Strange and Sublime Address (1991) stems from my observations on the cultural need of Bengali diaspora in India to connect to the culinary culture of Kolkata.

Among many markers of identity, members of the Bengali diaspora in America, as Krishnendu Ray observed in The Migrant's Table: Meals and Memories in Bengali-American Households, used their Bengali culinary practices both to assert and to assimilate themselves in the westernized global environment they inhabited. Ray's study is significant for this paper, since, as in Amit Chaudhuri's novella, it dealt with food experiences of the middle class - bhadralok - Bengali Americans who hailed from Communist ruled West Bengali. Ray's ethnographic analysis pondered how culinary practices helped Bengali Americans to come to terms with "social processes such as migration, modernity, and globalization" (4). Food, for Ray, is a place-making practice, and has a Foucaultian heterotopic iii effect on "the practices of local peripheral people, such as Bengalis who were made global through British imperialism, are then relocalized in an 
American suburb". Under such an effect, a suburb of Chicago, "can be many places: Bengal, America, India" (6).

Chaudhuri's idiosyncratic take on Bengali culinary culture in A Strange and Sublime Address (1991) has a similar heterotopic effect on his maternal uncle's house in Kolkata of the early 1990s. His culinary experience turns the house into a poetic dwelling - a dwelling of emotions, imagination and journeys - where he imagines the integration and disintegration of himself and the city. What Sandeep, the young protagonist, experiences is the resilience of Bengali life in its obsessive overattention to its food practices and the sociality of dining together. Culinary experience creates layers of emotional responses to both the dwellings - Kolkata and his maternal uncle's house. Further, Sandeep's experience of the city is deeply embedded in his journeys from the outer world - bahirmahal - to the private inner world - andarmahal and in his aesthetic preference for the cultural connotations of ancient, banal and quotidian household living in Kolkata. Saikat Majumdar has made thorough observations on Chaudhuri's preference for the banal and quotidian and has connected it to his objective of foregrounding the local subjectivities as against the national ones. The "idiosyncratic evocation of the local" through detailed depiction of dailiness, Majumdar writes, contests a spectacular and dramatic grand narrative of the nation $(448-450)$.

Chaudhuri carves his experience of Bengali food from his quotidian performance of merging with the city - a cultural merging that is evoked in his inner journey from an urbanized, flamboyant outside world to a reticent, bucolic inner world in home. For Sandeep, culinary experiences form, what Barbara Krishenblatt-Gimblett considers "edible chronotopes - "sensory space-time convergences" (xiii) which allow Sandeep, the young protagonist, to realize "the specificity of experiencing" Bengali food "on the spot, in relation to season ... freshness, perishability, and total world of which" (xiv) the food is part of in Kolkata. In this essay I provide a culinary context to Chaudhuri's A Strange and Sublime Address, which is filled with edible chronotopes that chart his banal and ambiguous journey to "bucolic" Kolkata. My primary aim is to highlight Kolkata's troubled relationship with food and hunger and its effect on Chaudhuri's novel. I argue that the symbolic resonance of Chaudhuri's expression "eating well" in Kolkata in A Strange and Sublime Address contextualizes food and culinary performances in Calcutta in the early 1990s. Eating well in one's maternal uncle's house - a popular Bengali proverb used in the text - situates the novel in a continuum of chronicity which coalesces themes like Bengali culture in the 1990s, Kolkata's struggle with hunger, its shabbiness, Marxism and Chaudhuri's personal journey to capture Kolkata in its glory. What Chaudhuri records is his esoteric merging with this glorified mundane in Kolkata:

Calcutta is a city of dust. If one walks down the street, one sees mounds of dust like sanddunes on the pavements, which children and dogs sit doing nothing, while sweating labourers dig into the macadam with spades and drills... Calcutta is like a work of modern art that neither makes sense nor has utility, but exists for some esoteric aesthetic reason. Trenches and mounds of dust everywhere give the city a strange bombed-out look. The old houses, with their reposeful walls, are crumbling to slow dust, their once-gleaming gates are rusting. Dust flakes off the ceilings in offices; the buildings are becoming dust, the roads are becoming dust. At the same time, dust is constantly raised into startling new shapes and unexpected forms by the arbitrary workings of the wind, forms on which dogs and children sit doing nothing. Daily, Calcutta disintegrates, unwhispering, into dust, and daily it rises from dust again. 


\section{The Bucolic City}

In Chaudhuri's recent writings, nostalgia for a glorious Bengali past has often been yoked with a desire to preserve the culture's forgotten glory in today's postlapsarian Bengal. Crusader-like, he has written a series of articles on the need to save Bengali middle class urban architecture from being bulldozed by modern property boom in different ancient parts of Calcutta/Kolkata ${ }^{\mathrm{v}}$. In July, 2015, The Guardian carried an article by Chaudhuri on his campaign to save urban architecture in the city. Further, an online petition form, to be sent to the Chief Minister of West Bengal and the Mayor of Kolkata, was attached to the article. All along the article, significantly enough, Chaudhuri used old British spelling Calcutta instead of its respelled Bengali endonym Kolkata. Renamed in 2001, Calcutta/Kolkata ${ }^{\text {vi }}$ and its melancholy decline features widely in Chaudhuri's novels about the city. As Calcutta/Kolkata's cityscape transforms with time, Chaudhuri tries to capture the city as a nostalgic continuity of the self. In newspapers and journals, he has written poignant essays on his inner connection to Calcutta/Kolkata. His volume of essays on his experience of the city Calcutta: Two Years in a City (2013) captures his changing relation with a city in flux. As the old houses are razed to the ground to make way for high-rises, Cahudhuri quietly buys a window with a venetian blind to preserve it from destruction (1-19). He theorizes Calcutta's modernity as urban decay, its egotistical isolation as its cultural trait and recognizes his "homesickness" for the city (70 - 89).

Chaudhuri has further theorized his experience of being inside the crumbling Calcutta coffeehouse as a quintessential experience of the paradox of modernity in an erstwhile Communist ruled city that had resisted globalization. In urban Bengali culture, coffeehouse has emerged as a traditional meeting place of reactionary intellectuals engaged in gossips on mourning the city's decline: ${ }^{\text {ii }}$

How do we situate the coffee house in India? For that matter, how do we situate shabbiness here? The task is a slippery one, because the taste for the frayed, the derelict, and the unfinished is barely acknowledged in relation to India, let alone categorized. This, I suppose, is true of the culture of shabbiness in any 'third world' nation that it must be subsumed in the narrative of underdevelopment. Today, especially, when the allocation of the globalized world into 'developed' and 'developing' countries is hardly questioned or scrutinized, the unfinished or the decaying must, in certain nations, always be seen to be a feature of underdevelopment (which progress will one day remove) rather than being at least in some quarters in those societies a strategically cultivated ethos.

\section{- (“On Indian Coffee Houses”)}

The appeal of the shabby, according to Chaudhuri, harkens back to India's deep socialist roots in Nehruvianism and Gandhianism, which inform an austere middle class ethos in India. It is an ethos that is deeply suspicious of excesses, privilege and ambition (2). This sense of shabbiness and banality, to which Chaudhuri connects eloquently, reflects his disavowal of India's national allegory: the narrative of colonialism, independence, and postcolonial development - ideas conveniently recognized as virtuous in the west. Instead of modelling his novels on established national allegories, Chaudhuri, maintains a critical detachment from the fascination with the dramatic and the spectacular ("Dallying with Dailiness" 450).

Life in Calcutta/Kolkata, in its diverse, idiosyncratic, mundane and fragmented forms, receives Chaudhuri's deeply sympathetic flaneuric gaze. For Chaudhuri, who grew up in swanky Bombay, writing about his childhood memories of visiting Calcutta/Kolkata in A Strange and Sublime Address was like travelling through the vicissitudes of space and time, of urban and a bucolic self. 
Calcutta/Kolkata, as Chaudhuri puts it, after years of Communist rule had ended up resisting globalization "cultivating their irrelevance to itself" ("My New Perspective" 3). The city, caught in its "economic stasis", conjured in him a counterpoint to a Mumbai-like "creation-myth for a new nation and its unprecedented, amoral provenance" (1). Instead of the seamless myth of development and post-liberalization "new India”, which Mumbai represents, Calcutta/Kolkata's shabbiness, to Chaudhuri, reflects a pastoral narrative. Pastoral narratives of the self in India, as Ashis Nandy reminds us, is "the utopia of idyllic, integrated, defragmented self, not tyrannized by the demands of atomized individualism" (Ambiguous Journey 13). Personal (read psychological) journeys, as Nandy reveals, either from the urban to the rural or vice versa can mean a desire for an escape, for a more refined self, for a fantastic mythology of travelling from one point to its counterpoint $(10-12)$. Chaudhuri finds in the fragmented modernism of Calcutta/Kolkata in the 1980 a counterpoint to the glitzy and successful Mumbai. Calcutta exists in its paradoxically bucolic urbanism:

This boundedness, this simultaneous obscurity and centrality, gave to what I found in my uncle's house its air of the bucolic, of being at once fantastic and real. Ordinary things the Bengali letters on the spine of a book; a toy; the cover of a children's annual; a photo album - became extraordinary, because I could sense they were deceptive markers of a great historical change of which I didn't know enough. When I came to write my first novel, A Strange and Sublime Address, about a 10-year-old boy from Bombay visiting his uncle's house in Calcutta, it was the quotidian, as a result, that became my subject. At the time - the late 8os - Calcutta, if it was at all thought about in the larger world, was hardly associated with the quotidian. It was famous primarily for Mother Teresa, and through Dominique Lapierre's book, City of Joy (about a real-life-inspired Polish priest working in a slum), and the film, starring Patrick Swayze, of the same name. For me, Calcutta's ordinariness was its most compelling feature - the word "strange" kept recurring in my tale of everyday objects and occurrences - and, to convey this, I had to go against the grain not only of a certain kind of narrative about that city, but also the sort of novel in which character and psychology on the one hand and historical sweep on the other was predominant. A Strange and Sublime Address was not going to be a novel of the nation. In fact, to write about Calcutta meant risking not writing a proper novel (in terms of plot and character) at all.

\section{- $\quad$ ("My New Perspective” 4)}

While writing A Strange and Sublime Address, Chaudhuri, aware of the lineage of various western representations of Calcutta/Kolkata, interiorizes culinary practices in urban Bengali household where quotidian food experiences reflect a range of human sentiments: from strange to cruel, familiar to idyllic, comfort to fear and anxiety. Food experiences bring Sandeep, the protagonist of the novella, close to antiquarianism and confirm his fascination for the unchanging life of his relatives in his maternal uncle's house. The episode which gives the novel its title, is itself bracketed by gastronomic desire of children conflicting with antiquated food habits of Saraswati, the maid. Abhi, Sandeep's cousin returns home from school hungry and roars to Saraswati for food, as Sandeep reads the "strange and sublime address" on Abhi's exercise book:
Abhijit Das
17 Vivekananda Road, Calcutta (South)
West Bengal, 
India,

Asia,

Earth,

The Solar System,

The Universe.

"Saraswati", Sandeep informs Abhi in hushed tones, "is not well", to which Abhi guffaws in disgust something "inconceivable" to Sandeep: "Why did she have to fall ill now?" (101) Unlike Abhi, Sandeep had learnt to pity Saraswati, "albeit with difficulty, for he usually reserved emotions like pity for beautiful orphan girls in stories or films" (100). Left alone in his mamabari by his cousins who were at school, Sandeep had begun to see "crumpled, ugly" and old Saraswati as "an individual" who "only spoke in a crude village dialect which was a huge source of amusement for children" (99). Monsoon got her ill, and she spent her days lying on the terrace lamenting her miserable condition. While being sympathetic to Saraswati, Sandeep develops his own set of culinary and temporal analogies. Saraswati, "stubborn" and "pigheaded" would not take medicines, but eat "bitter tulsi leaves": "She too was like the furniture in the house; many, many people had rested in her without knowing it. Old, decaying piece of furniture, never to be removed, giving rest again and again" (10o). Being a poor and old housemaid, living between pity and necessity, Saraswati's position in the house underscores the deep country-city divide in Bengal. Saraswati's improper Bengali ("rural dialect" as against the bhadralok urban Bengali) viii identifies her as one of the many Bengali rural poor migrating to Calcutta/Kolkata to live and work. Her near destitute condition, her lack of knowledge about her own age making her seem like an "eternity" (99) bring the spectres of hunger and poverty into Sandeep's mamabari. It is the same spectre which makes Mother Teresa and Dominique Lapierre famous (or infamous?) ${ }^{\mathrm{ix}}$. Chaudhuri has been keenly aware of Calcutta/Kolkata's representation as a third world "dump" as he writes in Calcutta: Two Years in the City:

And Calcutta had become, as the Americans might say, a dump. By the early eighties, Mother Teresa's profile as the face of eternity was so widespread that, in the Western world, this great city (mahanagar) of modernity, with its many contradictions and exacerbations, was seen as a present-day Galilee, a place of supernatural cures, of lepers awaiting the miraculous touch.

Within India itself, Calcutta had become a butt of jokes. This slow turn was fascinating; the former centre of 'culture', once admired for its eccentricity and waywardness, being ridiculed by other uppity cities like Delhi and Bombay for being obsolete.

From the middle of the twentieth century, international media, as Tapati Guha Thakurta chronicles, depicted Calcutta/Kolkata as an archetypal third world metropolis - an urban disaster. Lapierre's City of Joy was no exception. Much before Lapierre published his novel, there already existed an aesthetic tradition of depicting footpath dwellers in the city starving to death. In the 1940s, when the infamous famine hit Bengal, photographic representation of the city included portrayal of hungry rural millions dying on the streets of Calcutta/Kolkata. However, the insider perspectives of the Bengali photographers in Kolkata from the same era showed just the opposite - a city thriving amidst its intellectual traditions, art house films and haphazard urban development ("The Photographed City" 7 -8). Like Sandeep's fantasies about Saraswati, Chaudhuri 
has often depicted his earnest and a more involved interest in the poor in the city. Patronisingly, he had bought fast food for a beggar and her son and had listened to their life's stories (20 - 69).

\section{Food, Hunger and Poverty in Calcutta/Kolkata}

Calcutta/Kolkata's troubled relationship with food and hunger has long influenced its sociopolitical culture. Even before the devastating famine in the 1940s, food and proper diet were contested domains of debate. Jayanta Sengupta's essay "Nation on a Platter: The Culture and Politics of Food and Cuisine in Colonial Bengal" examines the nineteenth and early twentieth century debates on proper diet in Bengal. As Europeans living in the tropics were increasingly confused over the constituents of a healthy diet, Bengali nationalists in the late nineteenth century developed culinary treatises on standard Bengali cuisine in the tropics. Debates about relative merits and demerits of vegetarianism and non-vegetarianism appear to have merged with established notions of the orient versus the occident $(73-90)$. Later, during the famine in the 1940 s to the Food Movement of 1959, hunger continued to have both culturally devastating and politically transforming influence on the social life of Bengalis in West Bengal. Even in the 1990s, social scientists continued to point out the existence of widespread hunger in rural Bengal. Rajat Roy wrote as late as in 2008 about the failure of the Left Front government in West Bengal to alleviate chronic hunger ("Endemic Hunger"). Several volumes have been written on hunger as an aesthetic and its political ramifications in West Bengal ${ }^{\mathrm{x}}$. Mrinal Sen's movie Calcutta: 71 (1971) captures the effects of economic slowdown, hunger and the rising heat of social movements on the psyche of the city-dwellers in Calcutta/Kolkata in the early seventies. Among the four short episodes in the movie, one episode focuses on how imminent starvation leads household women to prostitution. Another shows how, amidst widespread shortage of food grains, young school going boys are smuggling rice off to black market.

From the Nihilism of these times had sprung nihilist aesthetics in Bengali poetry. Hungrealism, as the movement would be christened by its practitioners in 1962, was a portmanteau word from hunger and realism. The movement's poets - the Hungrealists - proclaimed themselves as belonging to hungry generation: the generation of the deprived, disaffected and miserable. For these self-styled Hungrealists, hunger was a literary aesthetic which they used to converse with their absurd desires and appetites. Their notoriety rocked the genteel literary society of Calcutta/Kolkata and provoked none other than the famous beat poet Allen Ginsberg. Hysterical, indecent, obscene and filled with grotesque imagery of devouring and consumption, the poems of the Hungrealists were meant to record "the ugly numbing truth that most men delight in these horrors, lust after their destruction, and fear life insanely" (McCord 31). In Bengali art and culture hunger has remained a powerful metaphor since the Food Movement. Widespread hunger further gave rise to the hope of abundance, the need for sharing and sympathy for the poor. The plays, especially Nabanna (Harvest) by Indian Peoples Theatre Association (IPTA), were prominent in spreading the ideology of sharing, socialism and hope. ${ }^{\mathrm{x}}$ Renowned Bengali filmmakers like Satyajit Ray and Mrinal Sen had made movies where food was not only an important theme, but also a powerful visual metaphor to arouse sympathy for the starving population. Ray's children's movie Goopye Gain Bagha Bain (1969) turns the spectre of starvation into an ironical boon of wish fulfilment. In the movie, impressed by Goopye and Bagha's musical talent, the lord of ghosts grants them three boons. When asked what boon they want, Goopye and Bagha invariably ask for a boon which lets them eat whatever they like. To the audience in 1969, the food the characters eat on screen remains as elusive as it is in reality. The world Goopye and Babha live in is sinister indeed. Here mad king's ministers withhold food from their subjects and 
blackmail them to take part in war. In a memorable scene, Goopye and Bagha disarm an entire marching band of hungry soldiers by magically pouring down cauldrons of sweets on them. The soldiers rush to secure the cauldrons forgetting war.

Like the movie, Chaudhuri's novella, as I intend to show in the rest of my paper, weaves a story around hopes of nourishment and abundance in Bengali households in Calcutta/Kolkata. Chaudhuri's choice of Calcutta/Kolkata as a locale for his Strange and Sublime Address in 1991 comes in the wake of a renewed interest in the city in the late eighties and early nineties. The city had started generating international attention with the publication of Dominic Lapeirre's City of Joy (1985). The novel, which follows the journey of a French doctor in search of spiritual awakening in the slums of Calcutta/Kolkata, was made into a film in 1992. Gunter Grass's hard hitting Show Your Tongue (1987) recorded his both repulsion and fascination with the city's poverty and its paradoxical liveliness. In 1988 Nicolas Klotz made Hugh Grant starrer The Bengali Night, which was based on an affair between a Bengali lady and a European engineer in 1930s Calcutta. In 1991, India International Quarterly, published by Indian International Centre in New Delhi, devoted its winter issue to Calcutta/Kolkata and titled it "The Calcutta Psyche". It contained poems, fictions and articles on different aspects of Calcutta/Kolkata as an interior landscape of the city's creative inhabitants. In the editorial titled "Portrait of A City" Geeti Sen writes that "Calcutta" in the eyes of poets and artists becomes the "Muse: seductive, a sorceress, bewitching ..." (3). She ends her essay with a poignant reminder of decades of famine, brutalisation and violence faced by the city. She writes of hope and rebirth after years of storm: "Gone is the mysterious Muse, the city of hopes and dreams. What will she bring in her twilight hour? Will there be a rebirth?" (4). Mrinal Sen too evoked similar sentiments in a short film Calcutta: My El Dorado (1990) which was part of a collage of twelve films on twelve different cities. A BBC Channel 4 documentary by Christopher Sykes in 1990 was yet another affectionate portrait of Calcutta/Kolkata as a lively city of contrasts. Sykes makes the viewers look at Calcutta from the perspective of its inhabitants. A tram conductor goes to work whistling, railway stations are filled with streams of smiling people, the city's intellectuals regret the economic downturn, its men jostle to buy statues of gods in the market. Not unlike Sykes, Chaudhuri too evokes the charm of the mundane in the city amidst its regrets and dreams of abundance.

\section{4. "Eating Well" in Uncle's House}

Early in the novella, Chaudhuri arrests Chhotomama (literally, younger maternal uncle) in an act of "eating well" in his house. This moment would be repeated in subsequent pages as the children in mamabari are fed and looked after by the adults, who envelop the house in a languid aura of abundance: "Though Chhotomama was far from affluent, they ate well, especially on Sundays, caressing the rice and the sauces on their plates with attentive, sensuous fingers, fingers which performed a practised and graceful ballet on the plate till it was quite empty" (Strange 10). In Bengali culture maternal uncle's house is where children are supposed to spend an ideal time. In nursery rhymes, "mamabari", as maternal uncle's houses are generally referred to, appears as children's utopia, where a child is loved, cared for and never punished. Mamabari is a place of abundance and dietary over-indulgence, as a common nursery rhyme in Bengali reveals:

Tai Tai Tai

Mamabari bhari moja/ kil chor nai

Mami dilo dudh bhaat/duare bose khai 
Mama elo chip niye/macch dhorte jai

\section{(Clap and Clap and Clap}

Mamabari so much fun/ no one hits me ever

Aunt served milk and rice/ I ate at the doorstep

Uncle has a fishing rod/ we go get some fishes)

The rhyme bestows separate responsibilities to uncle and aunt as guardians of their nephews and nieces. Uncle takes the children outside, and aunts serve them milk and rice ${ }^{\mathrm{xi}}$ at home. The children, in their turn, eat whatever is served happily, without any complaint. The boundaries of home and outside in the rhyme suit the clear spatial division of guardianship in Sandeep's mamabari. His uncle, a failed businessman, a "water-closet thinker" is forever hatching new business plans and driving his ramshackle car to his office. His aunt stays at home looking after the children and guests. Chhotomama, literally meaning, the younger uncle of Sandeep, lives in cloud with his Marxist notions of history, whereas Mamima, Sandeep's aunt, is gracefully feminine, reticent and unpretentious. Quiet, reticent women characters like her appear throughout the novella. They embody Sandeep's visions of a quiet, benign and graceful andarmahal - an inner space where food is cooked and served with care, and it is this food experience which sustains Sandeep's inner world - his life in andarmahal When Sandeep's uncle and aunt take him to visit their relatives far away from mamabari, the old man of the house - their host - watches over the dinner service adding that the delicious items were prepared by his daughter in law (Address 82), who never speaks during their visit. Neither is her name revealed in the chapter, but we get to know the name she chose for her baby daughter - Annapurna:

'Anna' means 'rice' or food, and 'purna' means 'full' or 'complete'; joined together, the two halves give birth (just as two parents had given birth to the child) to the word 'Annapurna' - Annapurna, which means Provider of Food or Sustenance, and is one of the many names of the mother goddess Durga.

$$
\text { - }(79-80)
$$

Goddess Durga is supposed to bless Bengali houses with the promise of abundant resources, and one of the founding myths of Durga Puja, an autumnal festival widely celebrated in Bengal, is about celebrations in maternal uncle's home. Durga, the Mother goddess, visits her earthly abode together with her children, who, in their turn, are visiting their maternal uncle's house on earth. Therefore, indulgent Bengali hosts welcome their divine nephews and nieces with religious rituals and celebrations that include abundant food offerings. In Sandeep's mamabari, "elegant and selfcontained" Durga has a prominent position beside her sons and daughters (42). In the quiet domestic inner circle of Sandeep's mamabari, his aunt, like a benign provider, prepares and serves food to everyone including the Gods. After taking bath each day, she offers food to the idols in her home with the conviction that the "...gods too are hungry ... They too need nourishment" (43). Caring and compassionate, Sandeep's aunt treats the all-powerful gods almost like her children arranging food-offerings for them with duty-bound attention. Sandeep, who is a non-believer and "sceptical but tolerant of other creeds" (44), is drawn to his aunt's act of worship in her small room surrounded by the idols, incense sticks and food-offerings - an act he terms "dignified uselessness". The prayer did neither matter to the gods nor to the devotees. What mattered was 
the act of worship which elevated meanings of food offerings like oranges, cucumbers and batashas to something above reality:

All that was important to the gods and the mortals was the creation of that rich and endlessly diverting moment in the small chamber, that moment of secret, almost illicit, communion, when both the one who prayed and the one who was prayed to were released from the irksome responsibility of the world. Oranges, white batashas, cucumbers.

Glorious in her graceful everyday ceremony, Mamima shields herself in her reticence. When Sandeep asks her about her prayers, she answers nonchalantly that she prayed that her husband's car would start in the morning (45). Earlier in the novella, Sandeep had sensed the reticent, mysterious persona lurking inside her when she had served tea and snacks:

She set the tray on the floor of the verandah, which had just been swept clean by Chhaya; then she bent her knees, slowly lowering her body, and sat down on the floor herself. She was most comfortable on the newly cleaned floor herself, her bright red and blue sari thickening around her, crumpling into several folds, her hands moving carefully though the minor storm of her garments as she served the sweetmeats. Her legs, like two romantic, indefinite paths on a mountainside, were lost in her sari's vast landscape.

When she prepares "jaams" for her husband, Sandeep witnesses her expertise in cooking: "solemnly but fiercely, she began to shake the pan up and down, holding it tightly in her hands" (30). When her son Babla cringes with an insect in his ear, she calms him down as she treats him with a drop of oil down his ear (97). Sandeep with his innocuous questions forges an intimate and rather playful friendship with his Mamima. He enjoys Mamima's mischievous answers to his questions about her marriage with Chhotomama (110 - 111) and finally, becomes her accomplice in protecting her andarmahal when she asks him to go to the terrace to guard her chilli plants, which she grows for her family, from bulbuls and parrots (110). Her benign nature keeps her andarmahal safe, but her bahirmahal, personified by her impractical "busy-body" husband and his ramshackle car, falls apart. Early in the novella, she tells a job-seeking young relative that her husband doesn't listen to her because he never has any time for her (23). In fact, it was the same reason, she would later tell Sandeep teasingly, why she never loved her husband (110). Her efforts to contain her husband with the care of her andarmahal receive a fatal blow when Chhotomama has a mild heart attack. Her world turns upside down. Finding her brother writhing, when Sandeep's mother calls out for Mamima, her conch - "heart of music at the centre of prayer ... stopped abruptly. In the distance, there was a sound of a plate being upset or overturned, and the soft, hurrying patter of bare feet" (129).

\section{Sandesh}

To a recuperating Chhotomama in hospital, Sandeep brings a box full of sweetmeats - "sandesh". Ubiquitously made by confectioners in Bengal, sandesh is a typically Bengali sweet made from cottage cheese. It comes in several flavours and sizes and generally appears as a dessert in elaborate multi-course Bengali meals. Culturally, sandesh is also given as gifts on auspicious occasions and to wish luck. Sandeep brings sandesh to Chhotomama as a sign of good times to come. But sweets make bedridden Chhotomama melancholy. The curving Bengali letters of sandesh remind him of the everyday humdrum of a sociable life in Calcutta/Kolkata: "of office- 
goers in the mornings, and homecomings in the evenings, of children reading books, of arguments and dissensions in the tea-shops" (143). He keeps asking Sandeep about the outside world and the state of annual festivities in the city (141-142). A hospital bound Chhotomama is a stark contrast to the vainly bustling man earlier in the novella, when, before rushing to his office, he used to be "the ordinary breadwinner in his moment of unlikely glory" (21) as Mamima and Saraswati "scuttled around him like frightened birds" (22). Like his foolhardy business ideas, his car needed prodding and pushing to run. And yet, he was a fervent debater on the dining table, which he used to drum to prove his point (29). It is around this dining table that the family and friends gather to discuss and bicker about their past, present and future. Sandeep writes that the table is regularly cleaned by Saraswati, but years of food stains have made it outwardly shabby but it had a "soul of a wronged criminal" (29). It is along this dining table, while eating jaams, that Sandeep's uncle mused on grand business solutions for global problems. On Sundays, the family spent hours around the dining table in endless arguments and gossips ( $57-59$ ). They discussed ways of helping young men in the family who had given up jobs only to philosophize about their own future. Chhotomama with his romantic notions about Marxism was no better than those philosophizing relatives, but the children including Sandeep "had boundless faith in him" (31). Only the grown-ups believed that he had no "head in business" (31).

To this prodigal Chhotomama, Sandeep's gesture of offering sandesh was his way of extending the care of andarmahal he had received from his Mamima. The women in the family extend their care with renewed zeal when they cook rohu fish for Chhotomama at home, now physically stable and getting well. In Mamima and his mother's renewed enthusiasm to care for Chhotomama, Sandeep sees a return to his earlier joyful, elevating moments of everyday living: "It was pleasing to see them being themselves; in the past two weeks they had talked only of expenses and mistakes and hopes ... it was pleasing to see them once more apotheosize and transform the present" (144). Sandeep's inner life is produced out of this apotheosis of everyday and out of his ability to absorb the world amidst a crowd. He keeps coming across sensitive characters like him who have confusedly merged with the sights, sounds and life in Calcutta/Kolkata. The courteous and garrulous Sikh taxi-driver reveals in a "mixture of disgust and reverence" how Calcutta/Kolkata he saw in a Hindi movie "absorbed him without his ever knowing it" (53). Sandeep had even fallen in love with a similar character - a vegetable vendor in the bustling market with a squint, who looked at him with one eye and the "other one was looking at the rest of the world" $(56)$. Everything in Calcutta/Kolkata has an attribute for Sandeep. Here objects "gleam" (4), utensils hold a dialogue before meals (6), fans swing "drunkenly" (7), radio cackles (12). Everyday living is so different from the quiet and "perfected" apartment life Sandeep led in Bombay (7). When he returns to Bombay after his holidays, he senses the death of his inner life. Bombay is "no sounds, no smells, only a pure, perpetually moving picture" (115). During his stay in Calcutta/Kolkata, Sandeep would often find his equilibrium disturbed when he remembered Bombay (36). To him, Calcutta/Kolkata is not merely a city in decline. Here, it is his desire for an inner life - an antarmahal - which makes him elevate the everyday into an experience of sustained joy.

As scholars like Partha Chatterjee and Ashis Nandy have shown, Chaudhuri is definitely not alone in creating a private mythographic sphere filled with ambiguous journeys from the urban to the bucolic. In fact, Foucault's heterotopia also indicates similar journeys from real space to an imagined space. Heterotopia further allows one to weigh human experiences both temporally and spatially. Sandeep, therefore, founds personal rituals to archive his experience of his dwellings. Like Chaudhuri buying a Venetian window to preserve a ruin, Sandeep memorizes the strange metallic sound made by a bhelpuri seller in the city (36). 


\section{Endnotes}

${ }^{\text {i }}$ Bengali diaspora is nationally divided between Bangladesh and India. Here, by Bengali diaspora I specifically mean Indian Bengalis.

ii West Bengal was ruled by a Left Front government from 1977 to 2011.

iii Foucault in his "Of Other Spaces" imagines two sites - utopia and heterotopia - which possess "the curious property of being in relation with all the other sites, but in such a way as to suspect, neutralize, or invert the set of relations that they happen to designate, mirror or reflect" (24). Heterotopia, as opposed to utopia (which are unreal/ideal places), is a mirror which opens up virtual spaces. Like a mirror that enables self-reflection, heterotopic sites indulge in an overlapping of real and imagined spaces. It constitutes simultaneous overlapping of "mythic and real contestation of the space". Foucault attributes five principles to heterotopia, among which the last three deserve mention. The third principle: "Heterotopia is capable of juxtaposing in a single real place several spaces, several sites that are in themselves incompatible"(Of Other Spaces 25). The fourth principle: "heterochronicities" which allows heterotopia to imagine time beyond its traditional symmetry. Heterotopia is a place which thrives on the accumulation of time e.g. a museum. The Fifth principle: "a system of opening and closing" which makes heterotopia a freely accessible place.

iv Several scholars and writers have used the emotional journeys from antarmahal to bahirmahal and vice versa as models to understand cultural imaginations. It has been used frequently to understand Bengali culture. In Partha Chatterjee's The Nation and its Fragments: Colonial and Postcolonial Histories (1993) home and world stand for the private spiritual self and the public material world respectively. Chatterjee hints at the cultural process of educated Bengalis cohabiting in two different domains - a private inner world, where the west has no influence, and a public world, where western materialism has taken over the statecraft and economy. Incidentally, The Home and the World (1916) is a novel by Rabindranath Tagore whose female protagonist Bimala experiences a journey from an Indian andarmahal to a bahirmahal influenced by western ideas.

${ }^{\mathrm{v}}$ The articles have been listed under Amit Chaudhuri in 'Works Cited' section.

${ }^{\mathrm{vi}}$ In this article I use Calcutta/Kolkata as a reference to a fervent cultural debate during renaming of the city in 2001. Even today, several urban residents prefer anglicized "Calcutta" to remind themselves of the city's rich and variegated colonial heritage. The cricket team Calcutta Knight Riders is a good example of marketable glamour of the city's English name. In the nineteenth and early twentieth century, Calcutta did enjoy the status of "Second City of Empire" (of course, second to London). Today, a mere google search for "Calcutta/Kolkata in decline" will produce several results with exact word match. For more, see Ananya Roy City Requiem.

vii Coffeehouse in College Street in Calcutta/Kolkata remains a romantic habitation for Bengalis. Dipesh Chakrabarty's influential Provincializing Europe discusses the emergence of coffeehouse as an urban space for gossip ( $a d d a)$ in Bengali upper middle class consciousness (201 - 204). Further, J Dhillon's "Great Expectations" records his disappointment at the shabbiness of coffeehouse in Kolkata. He recounts the history of the coffeehouse in College Street and evaluates its worth in modern day coffee retail business in India $(32-38)$.

viii For a detailed discussion on bhadralok see Anindita Mukhopadhyay. Behind the Mask: The Cultural Definition of the Legal Subject in Colonial Bengal (1775 - 1911). New Delhi: Oxford University Press, 2006.

${ }^{\text {ix }}$ Canonization of Mother Teresa as St. Teresa of Calcutta on September 04, 2016 by Pope Francis opened up many of these debates.

' Janam Mukherjee's War, Famine and the End of Empire explores cultural contexts of aesthetic representations of food and hunger in Bengali movies, paintings and literature. 


\footnotetext{
${ }^{x i}$ For more see "Lisa Lowe, David Lloyd (eds.) Politics of Culture in the Shadow of Capital. Durham: Durham University Press, 1997.

${ }^{\text {xii }}$ Dudh-bhaat or milk and rice is a locution symbolizing the security of abundance in Bengali language. A common Bengali turn of phrase includes the term "Dudh-bhaat" to wish prosperity for the future generation: "Chhele meye gulo jeno thake dudhe-bhaate" (May our children live in prosperity).
}

\section{References}

Austin, P. M. (n.d.). Local Histories, Global Perspectives in Amit Chaudhuri's A Strange and Sublime Address. Postcolonial Text, 6(2), 1-11.

Chakrabarty, D. (2008). Chakrabarty, Dipesh. Provincializing Europe: Postcolonial thought and historical difference. Princeton: Princeton University Press.

Chatterjee, P. (1993). The nation and its fragments: Colonial and postcolonial histories. Princeton: Vol. 11. Princeton University Press.

Chaudhuri, A. (1991). A Strange and Sublime Address. New Delhi: Penguin Books.

Chaudhuri, A. (2010, August 8). The Decline of Bengali Food - Bengali Cuisine is All about Aroma and Reticence. The Telegraph.

Chaudhuri, A. (2013). Calcutta: Two Years in the City. London: Penguin UK.

Chaudhuri, A. (2013, February 2). My New Perspective on Calcutta. The Guardian.

Chaudhuri, A. (2015, February 14). I Use the Things that Real Memoirists Throw Out. The Guardian.

Chaudhuri, A. (2015, June 28). On Indian Coffee Houses : The Appeal of the Shabby. The Telegraph. Retrieved January 31, 2017

Datta, S. (2013, September 13). Bengal to Bangalore. The Hindu.

Dhillon, J. S. (2014, November). Great Expectations but Nothing Fulfilled"- Indian Coffee House: A Case Study. International Journal of Management and Social Sciences Research (IJMSSR), 3(11), 32 - 38.

Foucault, M. \&. (Spring 1986). Of Other Spaces. Diacrtics, 16(1), 22-27.

Ghose, S. (2011). Khudarto Sangkalan. Kolkata: Dey's Publishing.

Gimlett, B. K. (2004). Foreword. In L. M Long (Ed.), Culinery Tourism. Kentucky: The Unviersity Press of Kentucky.

Kejriwal, L. (2006). Calcutta: Repossessing the City. New Delhi: Om Books.

Kirshenblatt-Gimblett, B. (2004). Foreword to Culinary Tourism. In x.-x. Lucy M. Long, \& L. M. Long (Ed.), Culinary Tourism (pp. xi - xiv). Kentucky: The University Press of Kentucky (.

Majumdar, S. (Winter 2007). Dallying with Dailiness: Amit CHaudhuri's Flaneur Fictions. Studies in the Novel, 39(4), $448-464$.

McCord, H. (2011). Poetry of the Hungry Generation. In S. Ghosh, Khudarto Sangkalan (pp. 31-32). Kolkata: Dey's Publishing.

Nandy, A. (2001). An Ambiguous Journey To the City: the Village and Other OddRuins of the Self in the Indian Imagination. New Delhi: Oxford University Press.

Nandy, A. (Winter 2002 - Spring 2003). Ethnic Cuisine: the Significant Other. India International Centre Quarterly, 29(3/4), 246 - 251. 
Ray, K. (2004). The Migrants Table: Meals And Memories in Bengali-American Households. Temple University Press.

Roy, A. (2003). City Requiem: Calcutta: Gender and the Politics of Poverty. Minneapolis: University of Minnesota .

Roy, R. (2008). Endemic Hunger in West Bengal. Economic and Political Weekly, 43(18), 21-25.

Sen, G. (1991/1992). Portrait of A City. India International Centre Quarterly: The Calcutta Psyche, 17(3/4), 1-4.

Sengupta, J. (2010). Nation on a platter: The culture and politics of food and cuisine in colonial Bengal. Modern Asian Studies, 44(1), 81-98.

Thakurta, D. T. (2006). The Photographed City. In L. Kejriwal, Calcutta: Repossessing the City (pp. 6 - 17). New Delhi: Om Books. 